\title{
Report (1966-1970) of the Subcommittee on Pasteurella, Yersinia, and Francisella to the International Committee on Nomenclature of Bacteria
}

14 August 1970

Mexico City, Mexico

A Subcommittee meeting was held on 27 July 1967 after the "Meeting on Pseudotuberculosis" in Paris (International Symposium on Pseudotuberculosis, Paris, 24-26 July 1967). Two short reports have appeared $(\mathrm{H}$. H. Mollaret, Sous Comité des Pasteurella, Yersinia et Francisella, Int. J. Syst. Bacteriol. 17:263-266; Subcommittee on Taxonomy of Pasteurella and Related Organisms of the International Committee on Nomenclature of Bacteria-proposed activities of the Subcommittee on Pasteurella and Related Organisms, Int. J. Syst. Bacteriol. 19:157-158).

The Chairman and the Secretary met at Erlangen, Germany, on 14 December 1968 and 25 May 1970 to discuss the activities of the Subcommittee and the comments on the circulars issued in 1967 and 1969.

Because the scope of the Subcommittee on Pasteurella and Related Organisms includes different genera and species which can hardly be dealt with competently by all members of the Subcommittee, special Working Groups with outside collaborators have been proposed. Working Groups on the following organisms have taken up their activities in the meantime: Pasteurella pseudotuberculosis (Syn. Yersinia pseudotuberculosis), P. pestis (Syn. Yersinia pestis), $P$. multocida, $P$. haemolytica, $P$. ureae, $P$. enterocolitica (Syn. Bacterium enterocoliticum, Pasteurella " $X$ ", Yersinia enterocolitica), and $P$. tularensis (Syn. Francisella tularensis). A list of reference strains is being prepared by the Subcommittee.

The Subcommittee accepted the transfer of Pasteurella tularensis to the genus Francisella as Francisella tularensis and of $P$. pseudotuberculosis and $P$. pestis to the genus Yersinia as $Y$. pseudotuberculosis and Y. pestis, respectively.

In the future the Subcommittee plans: (i) to intensify study of Pasteurella " $X$ " / Yersinia enterocolitica), particularly the biochemical, serological, and genetic aspects of this species at present there is not enough evidence to permit placing of this species in the genus Yersinia together with $Y$. pestis and $Y$. pseudotuberculosis, (ii) to reorganize the working group (Pasteurella, Yersinia, and Francisella) and to intensify the studies in the fields of biochemistry, antigenic structure, genetics, etc., (iii) to establish liaison with the ICNB Subcommittee on the Taxonomy of the Enterobacteriaceae after more information about $Y$. enterocolitica is available.

The next meeting of the Subcommittee is scheduled at Malmo, Sweden, in the spring of 1972.

W. Knapp and H. H. Mollaret were reelected to the offices of Chairman and Secretary, respectively.

The present membership of the Subcommittee is as follows: W. Knapp (Chairman), Erlangen, BRD; H. H. Mollaret, Paris, France; E. L. Biberstein, Davis, California, USA; T. W. Burrows, Porton, Near Salisbury, Wiltshire, England; G. R. Carter, Tifton, Georgia, USA; I. V. Domaradskij, Rostov-surDon, USSR; W. Frederiksen, Aalborg, Denmark; S. D. Henriksen, Oslo, Norway; W. D. Lawton, Fort Detrick, Maryland, USA; N. S. Mair, Leicester, England; I. L. Martinevskij, Alma-Ata, USSR; K. F. Meyer, San Francisco, California, USA; S. Namioka, Tokyo, Japan; N. G. Olsuf'ev; Moscow, USSR; J. E. Smith, London, England; and E. Thal, Stockholm, Sweden. 